\title{
Robin Mitchell-Boyask, Plague and the Athenian Imagination: Drama, History and the Cult of Asklepius [Cambridge: CUP, 2008]
}

Melody E. Mclntyre, Brock University

In Plague and the Athenian Imagination: Drama, History and the Cult of Asklepius, Mitchell-Boyask has given us a particularly self-aware book. Mitchell-Boyask looks at the effect the Athenian plague of the 430's on Athenian drama. He also draws a connection between the plague, drama, and the construction of the Asklepieion, the temple to Asklepius in Athens, which began in 420 BCE. MitchellBoyask wants to "discuss how a specific set of historical circumstances and cultural practices produced a theatre deeply preoccupied with social illnesses and their cures" (p. 5). Mitchell-Boyask's argument has three main components (p. 3). The first is that the imagery and language of disease becomes a living, not dead, metaphor after 430, due to the plague's influence. Second, that the construction of the Asklepieion next to the Theatre of Dionysus is a reflection of the Greek belief in the healing powers of song, and third, that the metaphor of the sick city becomes more prevalent in the years after the plague. The book is mostly successful in its aims, but does rely on some uncertain dating and stretches of logic to accomplish them. Mitchell-Boyask, however, is fully conscious of these stretches and helps the reader follow him on his journey to his conclusions.

The book focuses heavily on the plays of Euripides and Sophocles with brief forays into Aristophanes' and 
Thucydides' work. Mitchell-Boyask grounds his theory in his own branch of formalism, "contextual formalism". He is "using context as a complement to, not a substitute for, formalism ... in other words, context will be used to answer the questions raised by the close attention to form that form itself cannot answer" (p. 4). When discussing the plays, Mitchell-Boyask does rely on not just the context within the play, but the historical context happening at the time of the plays' production. The resulting analysis is effective.

Mitchell-Boyask divides his book into ten chapters, including introduction and conclusion. Chapters 3-6 focus on disease language, while chapters 7-9 examine the relationship between healing, poetry and theatre. Most of the chapters centre on individual or series of plays in a rough chronological format. Chapters three and seven are two halves of a set entitled Materials I and II. These two chapters step outside the plays to observe the effect of the plague from other angles. Chapter three examines the language used in the plays. Since the term loimos, "plague" is potentially taboo and is all but absent in Greek literature, Mitchell-Boyask discusses the use of the term nosos, "disease" instead (p. 23). He provides the reader with two charts counting the number of times nosos is used in each tragedy, one organized according to frequency and the other by date of production (pp. 29, 30).

This is one area where the book falls a little short. Mitchell-Boyask claims a direct connection between the frequency of the term and the plague, in order to prove his third argument about the increase in usage of the sick city 
metaphor. While there is a peak in its usage around the time of the plague, there is also a peak around 409-408 BCE. Mitchell-Boyask credits this second increase to the oligarchic revolution of 411 and the subsequent political upheavals (p. 31). I can not help but ask if it was really the plague that increased the use of diseased city metaphors or times of unrest in general. After the increases, the frequency returns to the prior level. While these points do not support Mitchell-Boyask's argument about the plague's effect on the metaphor, they do show that the metaphor is not "dead".

Furthermore, there is yet another peak in nosos frequency around the 440s in Prometheus Bound and Ajaxbefore the plague. Mitchell-Boyask attempts to downplay the significance of nosos usage in Prometheus Bound by pointing to its uncertain date and the potential idea that Aeschylus did not produce it (pp. 31,32). He spends some time arguing both sides of the play's authorship. Finding the idea "uncomfortably radical", Mitchell-Boyask does not propose that scholars should attribute the play to someone other than Aeschylus (p. 32). He then leaves Aeschylus behind for Euripides and Sophocles.

These charts, while interesting, do not add much to the idea that the plague changed conceptions of disease imagery in Athenian drama. They do reflect an immediate influence, but it dissipates over time. Mitchell-Boyask is also relying heavily on uncertain dating. He is aware of this fact and accounts for it in his discussion. There is nothing in the chart that directly contradicts his thesis. On the 
other hand, the chart does not lend as much support as Mitchell-Boyask seems to have wanted it to.

The other chapter in the "Materials" set discusses the cult of Asklepius and its connection to the Theatre of Dionysus. Mitchell-Boyask reasserts his second argument by pointing out that the Athenians likely did not decide to build the Asklepieion in this location simply because the space was free. The temple's location reflects associations between drama, healing, and the Athenian polis (p. 107). There is a strong connection between these three items, and Mitchell-Boyask asserts that connection by examining ritual and the placement of other temples to Asklepius in other poleis.

In the first chapter after the introduction, MitchellBoyask starts at the edges of mortality before narrowing in on disease. Death is insurmountable and bleak to the Archaic Greeks but, as they enter the fifth century, hope for a more positive life after death (or even reincarnation) surfaces (pp. 10,11). This atmosphere is more accessible to Asklepius, a deity destroyed for raising the dead. MitchellBoyask points to the idea that tragedy encompasses both a positive and negative assessment of death, and gives expression to a belief in positive and negative medical therapy (p. 11). The connection between drama and healing is expressed in tragedy's exploration of death and medical therapy. Sophocles was especially influenced by plague metaphor in his plays. Mitchell-Boyask devotes chapters to three of his plays Oedipus Tyrannus, Trachiniae, and Philoctetes. These plays build on one another to support Mitchell-Boyask's first and third arguments. 
The Oedipus Tyrannus is dealt with in the fifth, and strongest, chapter of the book. Aware of the vast scholarly time spent on Sophocles' Oedipus Tyrannus in a plague context, Mitchell-Boyask limits his discussion to a supplement of Bernard Knox's examinations of the plague and medical language in the play. ${ }^{1}$ Mitchell-Boyask detects a potential controversy in the play's production. The term loimos, "plague" is used within the play, which MitchellBoyask asserts would have been shocking to the audience (p. 65). The play also, depending on the exact dating, comes within a few short years of the plague itself. The influence of the plague on the Oedipus Tyrannus is made quite clear in this chapter. Mitchell-Boyask does a good job of showing how the play builds towards its single use of loimos. Greek plays are performed in an annual contest at the theatre of Dionysus, and the Oedipus Tyrranus finished second of three. Building on Knox's assertion that the Theban plague is unique to Sophocles, Mitchell-Boyask blames the play's second place finish on it "scraping violently at emotional wounds that had barely had the time to form scabs" (pp. 134-6).

Mitchell-Boyask's discussion of the Oedipus Tyrannus leads into his chapter on Sophocles' Trachiniae. Since the dating of this play is inconclusive, Mitchell-Boyask focuses this chapter on dating the play to sometime between 430 and 425 (p. 67). Seeing the Trachiniae as a plague drama, Mitchell-Boyask hopes to change way the play is seen by scholars. It is a drama engaged with the

1 B. M. W. Knox, (1956) "The Date of the Oedipus Tyrannus of Sophocles, " AJP 77, 1956, 133-47; Oedipus at Thebes. (New Haven, 1957), 139-147. 
worship of Heracles and as a reaction to the Peloponnesian War as well as the plague (p. 67).

After a brief rundown of previous dating attempts for the Trachiniae, Mitchell-Boyask begins building his case for the date. He finds an ally in Aristophanes' Clouds to help secure his date for the play. He credits the scene where Strepsiades awakens and laments the bug bites he received (Clouds 707-716) as a parody of Heracles' agony (Tr. 1008ff). If Mitchell-Boyask is correct, this would place Trachiniae before Aristophanes' play in 423, but still close enough to that date to remain fresh in the audience's minds. He follows this up by presenting Heracles' sufferings from the potion as a parallel to those caused by the plague as described by Thucydides. There is a resemblance between the two that cannot be ignored, and Mitchell-Boyask works to intensify this resemblance with his subsequent discussion.

The connection between Heracles' pain and the plague suffering does, at times, seem to be stretching the limits, but Mitchell-Boyask is aware of that and guides the reader along with him carefully. One area in particular is an uncomfortable leap, but the subject matter is itself uncomfortable. One of the symptoms of the plague is the loss of genitalia (Thuc. 49.8) and Mitchell-Boyask maintains that this may have happened to Heracles in the Trachiniae. Heracles does refer to himself as an unwed girl, a parthenos (Tr. 1071). Building on that reference and other cues in the play, Mitchell-Boyask lays out for the reader the idea that Deianira's gift unmanned Heracles. Mitchell-Boyask presents a potentially radical idea - a castrated Heracles - 
in a rather convincing manner worthy of consideration. If Mitchell-Boyask is correct that the plague was expressed through Heracles' suffering, this would help secure Mitchell-Boyask's arguments about the strength of the disease metaphors after the plague.

Another Sophoclean hero, whose nosos is similar to problems faced by Athens, is Philoctetes. Philoctetes was bitten by a snake and banished to an island. He lives there alone until he is recalled by Heracles and promised a cure. This cure is only possible if Philoctetes returns to a polis. Mitchell-Boyask equates this temporary exile with ostracism (p. 173). He also places the drama in the wider historical context of the period. Philoctetes was produced around the time of Alcibiades' recall. Mitchell-Boyask is uncertain about what point Sophocles is making about Alcibiades with this play, but he must have had recent events in mind when he composed Philoctetes.

From the Sophoclean chapters of the book, I now shift to a look at the two chapters on Euripides. MitchellBoyask acknowledges the doubts whether the extant Hippolytus is Euripides' second version of the play, or the first, but proceeds as if it were (p. 45). If it were the first, then the play would have been produced prior to the plague in the late 430 's, instead of after the plague in 428. He clearly demonstrates that disease imagery, especially surrounding Phaedra's passion, is prevalent in the drama. This could have been inspired by the recent plague. Mitchell-Boyask also places Hippolytus alongside Asklepius as they are closely linked in myth and ritual (p. 48). Once the Asklepieion is underway in 420, Mitchell-Boyask points 
to an intensification of disease metaphor in Euripidean drama that continues through the decade. He demonstrates this with a discussion of Heracles and the Phoenissae. The chapters on Euripides are engaging, and illuminate several areas for further exploration in these two plays and others, particularly Alcestis.

Mitchell-Boyask wraps up his book by reaffirming |449 the connection between Athenian drama and healing. The connection made is a strong one, as Mitchell-Boyask has effectively demonstrated. His discussion of drama in its historical context, and his treatment of the building and placement of the Asklepieion have reinforced this connection. Mitchell-Boyask has certainly revived the "dead" metaphor of disease in drama with this work. 